\title{
President Indonesia's Speeches: The Talk Meets Action in Functional Analysis
}

\author{
Risnovita Sari ${ }^{1}$, Ikhwanuddin Nasution ${ }^{2}$, Eddy Setia $^{3}$, Mulyadi ${ }^{4}$ \\ ${ }^{l}$ Student in Linguistics Doctoral Program in Universitas Sumatera Utara, Indonesia \\ ${ }^{2,3,4}$ English Lecturer at University of Gunung Leuser, Indonesia \\ Risnovita.sari@yahoo.com
}

\begin{abstract}
This study discusses the experiential function in Jokowi's speeches. The experiential function deals with the processes found in the speeches. There are six processes in the experiential function such as material, mental, verbal, behavioural, relational, and existential process. The study is aimed to identify the processes and find out the dominant process in the speeches. The speeches consist of 325 clauses, and the dominant process is material process with 124 clauses or $38,15 \%$, followed by relational process with 79 process or $24,3 \%$, mental process with 51 clauses or 15,7\%, existential process 33 clauses or 10,1\%, behavioural process 20 clauses or 6,1\%, and the least is verbal process 18 clauses or 5,5\%. It shows that Jokowi's speeches are the reflection of his slogan; 'work, work, and work'. Jokowi has done a lot of work and he explained it in his speeches.
\end{abstract}

Keywords

President of Indonesia;

speech, experiential

function; process

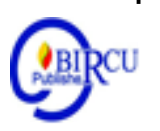

\section{Introduction}

When we talk about language, meaning making practice that happened in grammar. Carter \& McCarthy (2006:2) in Emilia (2014:23) explain that grammar is concerned with how sentences and utterances are formed. It is supported by Halliday \& Webster (2009: 3) stated that a grammar is that abstract stratum of coding between meaning and expression; it is a resource for making meaning, and then Halliday \& Matthiessen (2014:21) in their statement that grammar is the central processing unit of language, the power house where meanings are created; it is natural that the systems of sound and of writing through which these meanings are expressed should reflect the structural arrangement of the grammar. That is why grammar became the central processing unit of language within meaning making practices, because the clauses of grammar representing some process in a context produces the implicit meaning of text.

As the language user or linguist, the obligation we have to do is turning experience into meaning, and finally into wording. This study used the transitivity system as part of the experiential function because it has a necessary role to express ideational meaning in the public speech. According to Emilia (2014: 77) stated that the ideational meta function is to do with how language is used to represent experience, or to organize, understand, and express our perceptions of the world and our consciousness. Specifically, the experiential function belongs to ideational metafunction, and the transitivity system construes the world of experience into manageable set of process types Halliday (1994a:106), which is also termed as the clause as representation.

The three elements of the transitivity system -participants, process types, and circumstances - are, in nature, constructing the events (Bumela, 2012). So, from three experts 
above make the researcher curious to explore how the transitivity system belongs to experiential function occurs in public speech. Currently, we can see the real phenomenon that experiential function in ideational metafunction is more highly structured. The transitivity system, which is wished to provide guidance for the audiences about how the ideational meaning is created in the situational context. Then, it is become a crucial one because transitivity system of experiential function becomes one of ways to make our speech completely good. Experiential function concerns with the clauses that have guises. (http://repository.syekhnurjati.ac.id/2181/1/IKBAL\%20JAMALUDIN-min.pdf)

President Jokowi is known as the president who likes to work. He also has slogan 'work, Work, and work' for his cabinet. What he has done is reflected in his speeches. In his speeches, he always describes about his achievement during his time. The study of his speeches is matched using the experiential function since the experiential function analyse the text based on the experience of the speaker or writer.

\section{Review of Literature}

\subsection{Experiential Function}

Halliday (1994: 40) says that the ideational function is one of the meta function that has two sub functions: the experiential and logical function. The experiential functions concerned with content or ideas, while the logical function is concerned with the relationship between ideas. The experiential function is realized by the transitivity system. It strands of meaning will involve one major system, that of transitivity (process type), with the choice of process implicating associated participant roles and configurations. Transitivity choices will be related to the dimension of field, with the choice of process types and participant roles seen as realizing interact ants' encoding of their experiential reality: the world of actions, relations, participants and circumstances that give content to their talk.

Transitivity system belongs to experiential function. When we look at the experiential function, we are looking at the grammar of the clause as representation. It is called so because the clause in its experiential function is a way of representing pattern of experience. Through the system of transitivity, we can explore the clause in its aspects such as: who, does, what, to, whom, when, where, why, or how function.

When people talk about what a word or a sentence means, it is the kind of meaning that they have in their mind. Meaning in this sense is related to content or idea. So, here the clause is the most significant grammatical unit because it is the clause that functions as the representation of processes explores by transitivity system. Transitivity analysis offers a description of one of the structural stands of the clauses. Transitivity specifies the different types of function or process that are recognized in the language, and the structures by which they are expressed.

There are three semantic categories which explain in a general way, how phenomena of the real world are represented as linguistic structures. They are: the process itself, participants in the process and circumstances associated with the process. These provide the frame of reference for interpreting experience of what goes on. We use term process/function and participant in analyzing what is represented through the use of language. Processes/functions are central to the transitivity. They are on the part of the clause which are realized by the verbal group. They are also regarded as what "goings-on" and suggest many different kinds of goings-on which necessarily involve different kinds of participants in varying circumstances, while participants and circumstances are incumbent upon the doings, 
happenings, feelings and beings. Processes/functions can be subdivided into different types. (repository.usu.ac.id/bitstream/.../16407/4/Chapter\%20II)

There are six different process/function that are identified by Halliday (1994: 14):

a. Material Function is process of doing

Material Function is process of doing, that some entity physically does something and undertakes some action which may be done to some other entity. Clauses with a material function obligatorily have a doing (process) and a doer (participant). Actions involve actors or participants. The entity who or which does something is called the Actor. There optionally is an entity to which the process is extended or directed. This entity which may be done to is the Goal.

The term Goal implies meaning of "directed at". Goal is that participant at whom the process is directed or to whom the action is extended. Another term that has been used for this function is patient which means one that suffers or undergoes the action.

b. Mental Function is process of sensing

Mental process refers to verbs indicating perception, cognition, and affection (Emilia, 2014: 153). It is known as a type of process that relates to sense, feelings, thought, or perception (Eggins, 2004:225). In this case, the first participant related to the sense must be a conscious or human being is called by senser, and the second participant or the purpose will be named by phenomenon. There are many verbs which refer to these mental process, such as think, imagine, like, want, see, know, and heard.

c. Verbal Function is process of saying

Verbal processes of saying, as in what did you say? (Halliday,1994a). This process is tended to verbal communication. The potential participant roles, they are:

- A sayer as the participant responsible for the verbal process

- A receiver as the one to whom the saying is directed, it may be the subject in a passive clause

- A verbiage as the function that corresponds to what is said

- A target as the entity that is targeted by the process of saying.

d. Behavioral Function is process of behaving

Behavioral processes are processes of physiological or psychological behavior (Halliday, 1994a: 139). Here behavioral process related with something of physic or mental, which is the participant roles is behaver.

e. Existential Function is process of existing

Existential processes represent experience by positing that "there was / is something" (Eggins, 1994: 254) that something exist or happens" (Halliday \& Matthiessen, 2004). Existential process is describing about "exist" or existence.

f. Relational Function is process of being

Relational process involves states of being, including having (Halliday, 1994: 119). Relational process is typically realized by the verb be (am, is, are, was, were, been) become, seem, and appear or some verb of the same class (known as copular verbs). There are two classifications in relational process, they are relational attributive process and 
relational identifying process. In the relational attributive, the first participant will be named by Carrier while the second participant is called by Attributive.

Then relational identifying, the first participant will be named by Token, and the other participant will be named by Value. According to Eggins (2004: 242) said that typically the nominal groups in identifying intensive are definite, whereas in attributives the attribute is an indefinite nominal group. It means that there is no passive form in relational attributive otherwise it can be passive forms in relational identifying. It is happened because most of the first participant and the other participants are nominal groups.

\section{Research Method}

This study is principally designed on the data-and observation- based, and on the qualitative descriptive type of research. The research considers texts from multimodal perspective to include semiotic modes that accompany language or through which language is realized. The approach allows the incorporation of all relevant modes of communication that is a mode defined as a system with a set of rules and regularities attached to it.

The analysis refers to combination of theories which are able to describe certain semiotic codes such as the social semiotic approach developed by Halliday $(1985,1994,2004)$ known as Systemic Functional Linguistics (SFL). Language enables us to conceptualize and describe patterns of experience which was encoded in the clause as representation (experiential function) and dealt with the types of processes, the participants and circumstances associated with them.

The data of this study is limited into three selected speeches of Jokowi. The speeches are the inaugural speech, the speech in Asia Africa conference, and the speech in front of the parliamentary. Altogether there are 325 clauses from the speeches after classified.

\section{Analysis}

The first data is the inaugural speech of Jokowi. There are around 68 clauses found in the speech. From the analysis, it is found that the dominant process is relational process with 27 clauses, followed by material process with 17 clauses, existential process with 9 clauses, mental process with 7 clauses, verbal process with 5 clauses, and behavioural process with 3 clauses.

\begin{tabular}{|c|c|c|c|}
\hline No. & Process & Amount & Percentage \\
\hline 1 & Material & 17 & 25 \\
\hline 2 & Mental & 7 & 10,29 \\
\hline 3 & Verbal & 5 & 7,35 \\
\hline 4 & Behavioral & 3 & 4,41 \\
\hline 5 & Relational & 27 & 39,7 \\
\hline 6 & Eksistensial & 9 & 13,23 \\
\hline & & 68 & 100 \\
\hline
\end{tabular}

The second data is Jokowi's speech in the opening of Asia Africa Conference. There are around 61 clauses found in the speech. From the analysis, it is found that the dominant process is material process with 29 clauses, followed by relational process with 13 clauses, verbal process with 8 clauses, mental process with 7 clauses, existential process with 5 clauses, and behavioural process with 3 clauses. 


\begin{tabular}{|c|c|c|c|}
\hline No. & Process & Amount & Percentage \\
\hline 1. & Material & 29 & 47,5 \\
\hline 2. & Mental & 5 & 8,2 \\
\hline 3. & Verbal & 8 & 13,11 \\
\hline 4. & Behavioral & 2 & 3,27 \\
\hline 5. & Relational & 13 & 21,3 \\
\hline 6. & Eksistensial & 4 & 6,5 \\
\hline & & 61 & 100 \\
\hline
\end{tabular}

The third data is Jokowi's speech in front of the parliamentary on $17^{\text {th }}$ August 2017. Jokowi described what he had done during one year and how he took the responsible for the work. This speech is the longest one among all speeches. There are around 196 clauses found in the speech. From the analysis, it is found that the dominant process is material process with 78 clauses, followed by relational and mental process with 39 clauses each, existential process with 20 clauses, behavioural process with 15 clauses, and verbal process with 5 clauses.

\begin{tabular}{|l|l|l|l|}
\hline No. & Process & Amount & Percentage \\
\hline 1. & Material & 78 & 39,8 \\
\hline 2. & Mental & 39 & 19,9 \\
\hline 3. & Verbal & 5 & 2,5 \\
\hline 4. & Behavioral & 15 & 7,6 \\
\hline 5. & Relational & 39 & 19,9 \\
\hline 6. & Eksistensial & 20 & 10,2 \\
\hline & & 196 & 100 \\
\hline
\end{tabular}

The all data can be summed up into:

\begin{tabular}{|c|c|c|c|}
\hline No. & Process & Amount & Percentage \\
\hline 1. & Material & 124 & 38,15 \\
\hline 2. & Mental & 51 & 15,7 \\
\hline 3. & Verbal & 18 & 5,5 \\
\hline 4. & Behavioral & 20 & 6,1 \\
\hline 5. & Relational & 79 & 24,3 \\
\hline 6. & Eksistensial & 33 & 10,1 \\
\hline & & 325 & 100 \\
\hline
\end{tabular}

The number of the clauses are 325 clauses. The most dominant process is material process with 124 clauses. The second is relational process with 79 clauses. The third is mental process with 51 clauses. The fourth is existential process with 33 clauses. The fifth is behavioural process with 20 clauses. And the sixth or the last is verbal process with 18 clauses.

The material process is dominant because in his speech Jokowi explained what he had done during his period being a president. It is also in line with his slogan, that is, 'work, work, and work'. The relational process becomes the second since Jokowi explained many things to the audience. Verbal process becomes the least because it is a speech so the clauses about saying is seldom used. 


\section{References}

Eggins, S. (2004). An Introducion to Systemic Functional Linguistics (2 ${ }^{\text {nd }}$ Edition). London: Continuum International Publishing Group.

Emilia, E. (2005). A Critical Gene-Based Approach to Teaching Academic Writing in a Tertiary EFL Context in Indonesia Vol. 1. Unpublished. Bandung: UPI.

Emilia, E. (2014). Introducing to Functional Grammar. Bandung: PT. Dunia Pustaka Jaya

Firth, J.R. 1957. Papers in Linguistics 1934-1951. London: Oxford University Press.

Griffin, Em. 2003. A First Look at Communication Theory (5th ed.). USA: McGraw-Hill, Inc.

Halliday, M. A. K. 1978. Language as A Social Semiotics. London: Edward Arnold.

Halliday, M.A.K. 1985. An Introduction to Functional Grammar. London: Edward Arnold.

Halliday, M.A.K. 1978. Language as Social Semiotic: The Social Interpretation of Language and Meaning. London: Edward Arnold Ltd.

Halliday, M.A.K. 1994. An Introduction to Functional Grammar. 2nd. ed. London: Edward Arnold.

Halliday, M.A.K. dan Matthiessen, C.M.I.M. 2004. An Introduction to Functional Grammar. London: Edward Arnold.

Halliday, M.A.K. dan Ruqaiya Hasan. 1992. Bahasa, Konteks, dan Teks: Aspek-aspek Bahasa dalam Pandangan Semiotik Sosial. Penerjemah Asruddin Barori Tou. Yogyakarta: Gadjah Mada University Press.

Halliday, M.A.K., and Ruqaiya Hasan. 1985. Language, context, and text: aspects of language in a social-semiotic perspective. London: Oxford University Press.

http://www.iosrjournals.org/iosr-jhss/papers/Vol20-issue2/Version1/E020212229.pdfhttp://repository.usu.ac.id/bitstream/handle/123456789/16407/Chapte r\%20II.pdfhttp://repository.syekhnurjati.ac.id/2181/1/IKBAL\%20JAMALUDINmin.pdf 